\title{
Slums and Urban Development: Questions on Society and Globalisation
}

\author{
JEAN-CLAUDE BOLAY
}

The slum is not only a manifestation of mismanaged urban planning in the countries of the South. The existence of slums worldwide is also a sign that the slum is a crucial element of contemporary urbanisation. This article will attempt to define this phenomenon and understand its causes. Adequate policy responses are then suggested. Without finding appropriate solutions to the housing problems of a majority of urban dwellers, public and private decision makers will not be able to meet the challenges of sustainable development.

Le bidonville n'est pas seulement la manifestation d'une planification urbaine mal gérée dans les pays du Sud. Sa présence au plan mondial est également le signe que le bidonville représente une composante cruciale $d u$ phénomène contemporain d'urbanisation. L'article cherchera à définir ce phénomène et à en comprendre les causes, de manière à suggérer des réponses adéquates. Sans trouver de solutions à l'habitat de la majorité des citadins, les décideurs publics et privés ne seront pas en mesure de faire face aux enjeux du développement durable.

\section{INTRODUCTION}

The urban environment is highly complex. In the past, public policies have aimed at eradicating slums, without taking into account the potential of their inhabitants to resolve the very problems that slums reputedly generate. Especially in the contemporary era of globalisation, it is important to stress the resources that slums can offer the 'chaotic' city. This requires a reassessment of views on urbanisation. Sustainable urban development will only be possible if we concentrate on solving the problems of the majority of urban populations in ways that make use of their own creativity and involve them in decision-making.

According to a whole range of material, natural and socio-economic indicators on developing countries, spatial and demographic urban growth is characterised by the deterioration of physical, economic and social living conditions for a large and

Jean-Claude Bolay is Dr in Political Sciences, Professor and Director of Cooperation and Vice-President for International Affairs, Swiss Federal Institute of Technology, Lausanne. Email: jean-claude.bolay@ epfl.ch

The European Journal of Development Research, Vol.18, No.2, June 2006, pp.284-298

ISSN 0957-8811 print/ISSN 1743-9728 online

DOI: $10.1080 / 09578810600709492 \quad$ (C) 2006 Taylor \& Francis 
increasing part of the urban population. In this context, this article highlights the contradictions between housing-related practices, social mechanisms and public policies, as well as the need to define sustainable solutions which promote the wellbeing of the majority of urban dwellers. It is argued that there is a need to reconsider certain established approaches: ${ }^{1}$

- On the one hand, there is an exclusively sectoral, technological and local approach which posits a 'radiant future' for every poor city neighbourhood in the Third World, a future consisting mainly of better provision of water and sanitary services.

- On the other hand, a more realistic approach that accepts that, although the policies and plans of governments and international organisations may reflect a true commitment to solving the problems of the poor in urban areas, they are often ill-advised or wrongly conceived.

Against this backdrop, local, national and international policies have steadily evolved from repressive approaches aiming to eradicate slums and control the 'undesirable dwellers' (migrants and other social 'undesirables') to an assimilating view of the urban populations. From this stance, in its role as facilitator the state offers services and acts as a coordinator of policies and actions in the urban sphere. At best this strategy has resulted in improved legislation, collective infrastructure and services. At worst, however, it has tended to exacerbate corruption, and has forced the poor to become micro-entrepreneurs and become responsible for their own livelihoods. However desirable some aspects of this transition may be, it means that the majority of the urban poor are still living in highly vulnerable circumstances.

In a context of globalisation and of economic and political liberalisation, the result of such policies has been the impoverishment of poorer sections of the population, the explosive growth of the number and size of cities, and ever more complex and costly problems that need to be addressed. The innovative solutions proposed are too often unsustainable, and there is an apparent incapacity to go beyond orthodox planning and management approaches. This is in spite of the widespread acknowledgement that resolving the 'urban problem' in the developing countries is crucial. Based on previous research carried out by the author and colleagues, this article provides some indications as to how to overcome this impasse.

\section{SLUMS AND URBANISATION: UNIVERSAL AND SPECIFIC ASPECTS}

The extension of slums in developing countries is a product of 20th- and 21stcentury urban growth and represents the very essence of the Third World city. Attempts have been made to eliminate slums but they have almost universally failed because they do not question the urban model that generates the slum in the first place. In our own analysis of these causes, we suggest a three-track approach that requires taking into account citizens' demands and needs; evaluating the available resources (human, technical, financial, economic, social, organisational); and, 
finally, implementing urban governance in a way that fosters collective interests. To advance in this path it is necessary to promote a participatory approach in both social and political terms, adapted to the specific spatial and social context of each city.

The slum is characterised by the precarious nature of its habitat. But it is much more than that: it can genuinely be seen as a 'hothouse' of cultural creativity, economic invention and social innovation. Classic urban planning principles are based on comprehensive planning regarding land allocation, infrastructural organisation, and decisions on technical services and networks. In the slums, however, this technocratic approach is undermined by the social practices of individuals, families and social groups, particularly the poorer ones. These actors resort to their own emergency solutions to urban integration problems, and they do so at the micro-level at which these problems are posed - generally the plot of land, the house, then the district. In most cases the result is an individual or family construction on a plot of land which is occupied either illegally or by informal agreement, without being connected to the customary utilities. ${ }^{2}$ Although poor citizens recognise the importance of infrastructures and urban services for their wellbeing, they do not consider them a minimum requirement to move in. The immediate consequences of this situation are:

- for the users: buildings are of inadequate quality, town districts have poor infrastructure, equipment and collective services, and suffer various forms of environmental degradation;

- for urban planners, it becomes impossible to apply classical models of spatial organisation. It also becomes necessary to improvise remedial solutions based on existing social and territorial conditions.

This discrepancy may lead to two opposing tendencies: the denial of the 'social fact' by urban planners and the corresponding implementation of a repressive policy aiming to destroy whatever infrastructure or housing has been created outside official regulations and standards, and; the establishment of alternative policies aiming to reorganise and rehabilitate slum areas on the basis of what the resident communities have undertaken themselves.

The question of land ownership is one of the fundamental issues regarding slums in developing countries. In many poor areas of the city most people do not own the land on which they have built their house (Durand-Lasserve and Royston, 2002). In certain cases customary forms of land occupancy still exist, and the plot is allotted to a family by the local community. ${ }^{3}$ On rare occasions, this solution is legally recognised by the state. Generally though, land occupancy is wilfully ignored in favour of existing administrative, financial and regulatory procedures, often based on Western legislation imposed during the colonial era.

It has been estimated that between 25 and 70 per cent of urban dwellers in the developing countries live in irregular settlements (Durand-Lasserve and Royston, 2002). Secure land tenure is thus one of the major problems facing local and national authorities in these countries. For the United Nations, secure land tenure is a key 
element for the integration of the urban poor, as is their recognition by the public authorities (UNCHS, 1999). It can also encourage families to invest into upgrading their plots and diversify their use. This gives them protection against possible evictions and provides them with an asset that may serve as a guarantee in certain markets (e.g. for the purpose of acquiring bank loans).

Nevertheless, the solutions are not cut and dried: legal versus illegal, formality versus informality. They will depend on the political will of the authorities, the lobbying and negotiating capacities of the affected populations and on the innovative measures implemented to regulate land ownership. This perhaps lies at the crux of the problem: the vast majority of the urban poor suffer precarious forms of territorial integration, leaving much scope for conflicts between urban investors and the social needs of local inhabitants (Farvarcque-Vitkovic and McAuslan, 1993).

Land ownership is not of course the only issue that bedevils the poor residents of the cities in the South: access to collective services and infrastructures is an indispensable part of all urban integration policies. The poor are poor because they also have difficulty accessing urban services; moreover, when they finally obtain this right its cost is proportionally higher than for other urban groups. Following the recent evaluation of the United Nations on the Millennium Development Goals (2005), access to clean drinking water and to wastewater treatment facilities has improved during the past 10 years. ${ }^{4}$ But although the situation in urban areas is better than in rural regions, the problems are by and large similar: collective facilities and major infrastructures (roads and water) are inadequate, the socio-spatial distribution of services is selective, public-private partnerships are applied in an incoherent manner, administrative and financial management is inefficient, and maintenance is poor.

\section{SLUMS AS A MEASURE OF URBAN GROWTH}

The slum question is not marginal to urban development - it is at its very heart. Urban growth takes place primarily in developing countries in which populations move from rural to urban regions at a very fast pace. According to UN-HABITAT (2003), 'some 923,986,000 people, or 32\% of the world's total urban population, live in slums; some $43 \%$ of the urban population of all developing regions combined live in slums; some $78 \%$ of the urban population in the least developed countries live in slums; some $6 \%$ of the urban population in developed regions live in slum-like conditions'. ${ }^{5}$ The total number of slum dwellers in the world increased by about 36 per cent during the 1990s, and in the next 30 years the global number of slum dwellers will increase to about two billion if no concerted action to address the challenge of slums is taken.

In both territorial and demographic terms, the world is becoming more and more urban. This process now affects above all the developing countries in Asia and Africa, and Latin America to a somewhat lesser degree (where the level of urbanisation is already exceedingly high). The rate of urban growth in many countries in the South continues to be high, and invariably leads to a serious 
degradation of living conditions for the majority of city dwellers. The figures quoted in the UN study speak for themselves: depending on the level of poverty in each country, between two and four city dwellers out of five live in slums, with significant consequences for their own lives and the lives of coming generations: precarious conditions for them, uncertainty for their offspring.

The scale of the urban-rule shift is more perceivable if looked at in historical perspective. In 1800 a mere three per cent of the world's population lived in an urban environment, a proportion that rose to 14 per cent in 1900 and to 30 per cent in 1950. In the year 2000, 47 per cent, that is, almost half of the 6,055 million inhabitants of the world were city dwellers -76 per cent in the developed countries and 40 per cent in the less developed ones. Globally, this proportion is likely to reach 60 per cent by 2030, due primarily to urbanisation in the developing world. This trend goes hand in hand with an explosion of metropolitan centres of over one million inhabitants. Worldwide, there were 12 such cities in 1900, 83 in 1950, and 411 in 2000. Nevertheless, in 2003 the United Nations Population Division confirmed that a majority of the current three billion city dwellers - who will become five billion by 2030 - still live in small or medium-sized urban agglomerations. In the developing countries, 16 per cent of the population live in a megalopolis of over five million inhabitants, 24 per cent in a metropolis of one to five million, 9.4 per cent in an agglomeration of 500,000 to one million inhabitants, and 50.5 per cent in cities of less than 500,000 inhabitants (United Nations, Population Division, 2003).

Confronted with this demographic and territorial revolution, urban decision makers are often placed in a very difficult, if not impossible, situation. Sometimes this is due to a lack of political will, but more often it is the result of a lack of financial resources.

\section{LIVING CONDITIONS OF THE POOR: AN OVERVIEW OF URBAN HISTORY}

The precarious conditions in the developing countries should not blind us to the fact that poverty, environmental deterioration and social segregation are by no means only to be found in the poorest countries on our planet. Such a view would overlook major aspects of urban history, and socio-spatial disparities that even today cause Western cities to tolerate poverty zones. Using household waste as an example, Lieberherr (1998) reminded us that between the 12th and the 19th centuries unsanitary conditions prevailed in the French capital without causing a particular outcry among the citizens. Similarly, in his novel Water Music (1982) NorthAmerican writer T.C. Boyle describes London's poor districts in 1795, at the time that Scots explorer Mungo Park discovered the African kingdom of Ségou. At the end of the 18th century the British capital was very much like the most depressed areas of contemporary cities in the Third World. ${ }^{6}$

Urban poverty in the industrialised countries is not only a historical fact undeniably, it is still with us. An article in the Monde Diplomatique (Vaillant, 2000) informed readers that the Portuguese government had just launched a special relocation program, earmarked at over one billion euro, in which 150,000 persons living in 'barracas' between Lisbon and Porto were to move to more adequate 
housing. Although as stated by Ruffin (2003), most slum-dwellers live in the urban agglomerations of developing countries, it is estimated that six per cent of urban dwellers in the rich countries live under extremely precarious conditions, while public expenditure for subsidised housing and urban rehabilitation is spiralling downward. Further shortages and even more precarious living conditions may be feared as a result.

This makes it clear that regardless of the city or region of the world, poverty and precarious habitat are intimately connected. The French Institute of Statistics and Economics (INSEE, 2004) has confirmed this in France via its definitions and urban poverty indicators: a concentration of low-income households, over-population, a lack of basic material comforts, territorial localisation (between city centres, peripheries and sensitive urban areas), poor transport networks and access to urban services. Studies conducted in Canada during the 1990s also confirm the link between poverty and urban phenomena. Poverty increased significantly between 1990 and 1995, going from 4.2 to 5.5 million people, primarily in urban areas. Most poor citizens live in the city centres, where the main economic activities are concentrated. This is due to the types of housing they have access to, and to the facilities provided by the proximity of public services. Ruffin (2003) estimates that in France approximately one million households are inadequately housed, or have no housing at all. Although the official discourse revolves around the fight against poverty and social disparities, funding for subsidised houses is being cut. The practices of social segregation and spatial fragmentation best explain these developments, and they are universally applicable. The truth is that the trend towards discriminatory and inequitable urbanisation is found everywhere, in both rich countries and poor ones.

FROM HOUSING TO DISTRICT, FROM DISTRICT TO CITY - THE INTERFACES OF PARTICIPATORY URBAN POLICY

The 'urban question' is thus clearly multi-faceted and multi-dimensional. The various research projects and urban development activities that have been implemented by the Swiss Federal Institute of Technology, Lausanne (EPFL) for nearly 20 years in Latin America, Africa and Asia have made us receptive to the plural and association-based approach to urban planning at different levels: intraurban, urban-rural, regional-national-world. We also feel it is fundamental to acknowledge fully the contributions of specific players (public, private and community-based, both on an individual and institutional level) and take into account the opinions of a plethora of professional groups (architects, urban planners, technicians, administrators, economists, finance specialists and social scientists).

A scientific cooperation project between Vietnamese and Swiss social scientists, engineers and architects that lasted almost eight years deepened our understanding of the interactions between precarious habitats, poverty, social exclusion and spatial planning (Bassand et al., 2000; Bolay, Thai Thi Ngoc Du, 1999; Bolay et al., 1997). The Vietnam project established a link between the natural and the man-made environment, highlighting two dimensions which provide a better understanding of urban slums. This type of research activity aiming at providing innovative policies 
and urban programmes corresponding to the needs of a majority of citizens was the focus of a project funded by the Swiss Agency for Development and Cooperation (SDC). In cooperation with the Bolivian Ministry for Urban Affairs, a team headed by the Swiss Federal Institute of Technology in Lausanne attempted to put into practice a presidential decision to supply subsidised housing for the poorest citizens (Bolay, 2002). ${ }^{7}$ Two facts symptomatic of the difficulties which confronted urban dwellers in Bolivia at the time: the informal urban sector caused by macro-economic changes grew from 43 per cent in 1976 to 55 per cent in $1987^{8}$ (Pradhan and van Soest, 1995); and, in 1992, a CEPAL study estimated that there was a shortage of some 270,000 housing units. ${ }^{9}$

Instead of asking the population to adapt to existing regulations and institutions, the research project took the opposite stance and asked the questions: 'Who are these urban poor in need of housing?', 'What conditions do they live in?', and 'What are their aspirations and what are they willing to do to improve their situation?'. A group of experts, including representatives from academia, finance, the government and civil society attempted to answer these questions in two steps: first by looking directly at people's socio-economic and housing conditions; then, by examining the reasons for the malfunctioning of an existing public housing credit system that marginalises those without a fixed salary, particularly low-income families (Bolay, 1998). The conclusion reached was that a change of perspective was required: it was necessary to find financial backers prepared to grant credit on a different basis, adapting them to the reimbursement capacity of the parties in question and to the speed with which they could execute construction (unlike salaried workers they build their houses themselves, working as fast as their private and professional lives allow). ${ }^{10}$

This kind of participatory logic is essential for sustainable urban action. And it was this aspect that failed in the restructuring and urban planning project in the Nylon zone $^{11}$ in Douala, Cameroon. The World Bank and the SDC had joined forces with the national government to rehabilitate a part of the city at the infrastructural, housing and socio-economic level. Douala had suffered high levels of demographic growth and official neglect; in 1980, the 13 districts of the 'Nylon' zone were home to almost 20 per cent of the city's population: there was no drinkable water, no wastewater processing or garbage disposal system, no asphalt roads, no public schools or health care centres in the area. The project called for the construction of the roads and drainage systems, the installation of collective services, and also the regulation of landownership, housing credits, the relocation of families affected by the works, the promotion of crafts and other types of employment, and support for basic community organisations. This was, in other words, a truly 'integrated' urban project" (Bolay, 1988).

The project would never have seen the light of day without civil society and community organisations in these districts. But what happens when such local initiatives are taken over by an international development project? The scope, methods and intervening parties inevitably change. In 1983, the government of Cameroon signed a first agreement with the World Bank for US $\$ 55$ million of which 36 per cent was lent by the World Bank, 10 per cent by the SDC and the rest by the government. In the end costs skyrocketed, with expenses up by between 50 to 200 
per cent (Gulyani and Debomy, 2002). There was widespread dissatisfaction at the lack of commitment by government authorities, and inhabitants felt excluded by the complexity of institutional structures. Established social practices were marginalised. The residents, mostly migrants of rural origin, had previously organised themselves in order to cope with the most pressing problems prior to the launch of the rehabilitation project, building schools, paths, drains, etc. As the project developed they found themselves progressively eliminated from decision making and relegated to the status of passive onlookers as officials struggled to regulate housing and landownership.

This brief overview of three case studies, highly representative of the problems that confront players in urban agglomerations in developing countries, tells us a lot about the issues that link urban planning and the organisation of a healthy and vibrant urban environment. ${ }^{12}$ Without overly simplifying issues that everyone knows to be complex, resolving the problems of planning and organisation requires intervention at three levels:

- The first level is at the level of the neighbourhood, and involves interaction with local authorities, grassroots community organisations, families and individuals. The aim here is to delineate the immediate and more remote problems the residents deal with (gainful employment, schooling for children, housing, sanitation and health) in order to examine their local and wider consequences, possible remedies and their costs.

- The second level is at the district/city level. Urban planners and decision makers need to account for community dynamics and for the changes they bring about in each city area.

- The third level refers to the region surrounding the city, since any change in the city has a direct impact on the hinterland, or even beyond. It is therefore important to know more about the types of interactions that evolve between an urban agglomeration, region, country, and the global world community, in order to make informed political and planning choices for the benefit of the city (Bolay and Rabinovich, 2004).

Such a multi-level approach highlights the inconsistencies and contradictions that may occur between social dynamics generated by the inhabitants themselves and decisions made by authorities and implemented in the city (these may be technical or transport networks, the provision of services, zoning, etc.). Put side by side, these contradictory choices and political or financial priorities may help redefine urban planning to make it more strategic, flexible and adapted to the existing socio-spatial context - and above all more attentive to the needs and demands of the citizens.

Let us review the key elements of sustainable development (Sachs, 1997) so as to be able to apply its tenets to urban territories. There are three elements which need to be balanced:

- the environment, which requires judicious and informed management;

- the social sphere, in which an equitable distribution of goods, services and other benefits of economic growth is a key objective; and 
- the economy, which will not only aim to be profitable and create material and financial wealth, but will also strive to internalise indirect production costs. ${ }^{13}$

These three key elements of sustainable development, applied to the urban context in developing countries, should be linked to three complementary objectives: territorial planning to avoid an increase of spatial disparities; inclusion of the cultural sphere in order to account for anthropological, historic and symbolic dimensions; and inclusion of the political sphere which provides a regulatory, legal and democratic framework for the changes resulting from the application of sustainable development principles.

\section{SLUMS AND SUSTAINABLE URBAN DEVELOPMENT IN THE AGE OF GLOBALIS ATION}

As we documented earlier, the urbanisation of the world is not a new phenomenon; in fact it is a long-term process that has transformed our societies over the centuries. People congregated in towns and cities, took up increasingly diverse economic activities, and there was a shift from agriculture and husbandry to crafts, trades and industry. Historically speaking, these social and economic changes implied the consolidation of human activities in ever more concentrated human settlements, which facilitated production, trade and other forms of exchange between individuals. Improved communication technology is paving the way for a new spatial distribution of individuals - connected 'virtually', but sometimes physically remote.

The city - and its current mutant forms such as urban agglomerations, metropolization, and metapolization (Ascher, 1995, 2000) - was and is at the heart of the restructuring of human societies. The role of urban centres changes throughout history - and also varies according to the continent - but their central position remains. The conditions for their sustainable development cannot be determined uniquely by internal contingencies. Cities and their inhabitants depend heavily on external resources - energy, natural resources, food, labour. On the other hand, the economic and social activities of their residents generate impacts that go well beyond their spatial and demographic boundaries. Only by analysing the interaction between the city, regional, national and international development will it be possible to design a 'sustainable coherent development strategy'.

Existing economic and political relations between the North and the South are characterised by the fact that the use of existing resources, access to services and infrastructures, and consumption of these goods is increasingly inequitable (Carley, 2001). ${ }^{14}$ On all continents, another socio-spatial division that is becoming increasingly apparent is the primacy of urban centres over rural regions, and - in the urban network - the rising supremacy of very large agglomerations over secondary and intermediate cities. This metropolisation process is evident in the most industrialised countries (Bassand, 2004), and is gathering speed in the developing regions. Limits on financial and human capacities give an unquestionable advantage to metropolitan centres and large agglomerations 
'connected' to major national and international networks. This in turn influences political and economic decisions as to public and private investment in planning, collective goods and economic infrastructure.

Urban centres drive economic growth. This is evident in the industrialised countries, but also in Latin America and increasingly in Asia. Scale economies, increased productivity and the concentration of specialised skilled workforces are some of the factors that explain this link between urbanisation and the economy. The latter is highly visible in terms of the estimated contribution of the urban populations to GNP ( 55 per cent of the GNP in low-income, 73 per cent in middle-income, 85 per cent in high-income countries). ${ }^{15}$ The urban primacy in the economic field goes hand in hand with international disparities and more and more precarious urban centres owing to the growth of slums. Intensified trade linkages tend to consolidate this bipolar division of the urban world into 'winners' and 'losers' (Bolay, 2004).

Advanced information and communications technologies (ICT) offer economic and political decision makers scope for faster and greater activity; they also give rise to powerful but volatile and unforeseeable migration movements. Weisbrot et al. (2001) demonstrate the extent to which deteriorating terms of trade hit the poorest countries hardest. The rift between the rich and the poor has deepened over recent decades and only a few countries (principally in East Asia) have been able to lift themselves out of poverty.

In this context cities are both a 'paradise and a jungle' for their residents and those who aspire to become residents, hoping in their turn to benefit from the accumulation of opportunities that cities embody. As noted earlier, urbanisation will continue on a global scale for the foreseeable future. In 2007, the world's urban population will equal its rural population; in 2030, it will represent 60.2 per cent of the overall population of our planet ${ }^{16}$ (United Nations Population Division, 2002), that is, almost five billion people, four billion of these in developing countries, out of a total world population of 8.27 billion.

The combined dynamics of demographic growth, urbanisation, trade globalisation and the spread of advanced technologies, deregulation and increasingly precarious social conditions all combine to create the impression that in developing countries urban areas will continue to grow in a dual discriminatory fashion: territorial fragmentation, with increasingly limited areas of prosperity and wellbeing surrounded by areas of social exclusion. This process will be marked by increasingly informal relationships, particularly in the economic sphere, giving rise to individual and social insecurity. Against such a backdrop, the slogan launched by the UN in its Human Settlements Program (UNCHS, 2003) of 'cities without slums' appears to be based more on an act of faith than on analysis.

From a critical perspective, then, progress needs to be made on four different fronts:

- The most important priority appears to be the creation of a concerted policy to combat slums (and more generally 'inequitable' urban development) in a fundamentally structured manner, backed by political authorities on all levels and designed over the long term. Overcoming disparities and social inequity calls 
for the mobilisation and involvement of all stakeholders, particularly the participation of inhabitants and their representatives. ${ }^{17}$

- It is possible to detect a certain 'political indifference' towards the major issues of urbanisation in the developing countries. Instead of expecting inhabitants, especially the poorest ones, to adapt to ad hoc bureaucratic and administrative practices that encourage social exclusion and clientelism, an alternative approach is needed to rebuild urban and national legal and regulatory frameworks adapted to the population's needs and capable of responding to sectoral demands.

- There is a need to challenge the neo-liberal bias in structural adjustment programs that disempowers public authorities and disadvantaged urban populations by making the economies of Third World countries increasingly 'informal' (Lautier, 1994; Sethuraman, 1997; World Bank, 2001). Going beyond such basic considerations as employment and income generation, poverty reduction and access to basic goods, the urban economy should be redesigned as a driving force of development that is both socially and environmentally acceptable. It needs to be innovative in its use of technologies, and act in a way so as to redress territorial imbalance.

- Due to the combination of a lack of access to credit and precarious personal circumstances, many urban households are forced to seek alternative forms of credit which are socially and financially burdensome (e.g. usury, pawnbroking, mafia sources). This inadequacy of the banking system to serve clients who are numerous but have low income generates very heavy indirect costs for the whole of society by encouraging illegal landownership and construction, the spread of anarchic patterns of land use, and the use of low-quality building materials. Alternative solutions for the construction and financing of subsidised housing for the poor do exist. These have been tested in various cities in the world; they all revolve around a few key innovations: micro-credits, family and community guarantees. ${ }^{18}$ Like the other institutional change described above, they aim to adapt the financial system to the needs of the inhabitants rather than the other way around.

If policy was reorientated in this way, it could truly contribute to tackling the main urban dysfunctions observed earlier, and help fulfill the Millennium Development Agenda (UN, 2000): to contribute to the eradication of extreme poverty and hunger by reducing the proportion of people whose income is less than US $\$ 1$ per day by half by 2015; by reducing the number of people without access to healthy drinking water by 50 per cent by 2015; and to significantly improving living conditions for at least 100 million slum dwellers by 2020 .

\section{CONCLUSIONS: SLUMS AND EQUITABLE CITIES}

A wealth of examples proves that public policies fostering sustainable and socially equitable cities are possible, both locally and nationally (Wakely and 
You, 2002). In her conclusion to 'Building Sustainable Urban Settlements' (Romaya and Rakodi, 2002), Rakodi draws on numerous studies conducted in all the regions of the world and defines several requirements for sustainable change: a regulatory framework effective enough to control the environmental impact of urban development; enhanced organisational capacities of municipal administrations, the reinforcement of community-based organisations; mutual respect for the legitimate interests of other urban stakeholders, and the sharing of the benefits from cooperative efforts. Evans (2002) integrates these issues in a more overtly politically-oriented vision of sustainable urban development. He first acknowledges the growing domination of the global economic market, which not only influences the environmental aspects of urban development, but also focuses the debate (and thus the minds of decision makers) on the political struggle for comparative advantage in the world market to the detriment of local interests. In this context, the three major players - communities, non-profit organisations and state institutions - must seek synergies to defend and promote the common good in the urban sphere.

This form of protection against market forces should not be seen as 'a throwback to another era', as some critics would undoubtedly label it, but rather as a contemporary strategy aimed at integrating different scales of social and political interaction, a 'glocalization' phenomenon in the term coined by Ascher (2000: 147). We must break out of the vicious circle of urban impoverishment and environmental degradation by taking the slum for what it is - an urban habitat that has deteriorated and must be rehabilitated and organised jointly with the full participation of its inhabitants (Percq, 1994).

\section{NOTES}

1. According to the National Centre of Competence in Research on Mitigating Syndromes of Global Change (NCCR N-S) (cf. Hurni et al., 2004), the slum (identified as the 'favela syndrome'; Kropp et al., 2001) is a form of 'socio-ecological degradation through uncontrolled urban growth', characterised by strong negative impact in the following areas: soil degradation, fresh water scarcity and global development disparities. The 'urban sprawl syndrome', a second characteristic of worldwide urbanisation, leads to the 'destruction of landscapes through the planned expansion of urban infrastructures', and generates soil degradation, climate change, loss of biodiversity and fresh water scarcity.

2. The first things that come to mind are drinking water provision, wastewater disposal, electricity and a fixed telephone network.

3. According to traditional rules that are respected and approved by ethnic or religious authorities.

4. In developing countries, the population having access to clean drinking water has moved from $71 \%$ in 1990 to $79 \%$ in 2002 , and from $34 \%$ to $49 \%$ for access to sanitation facilities.

5. See <www.citymayors.com/report/slums.html $>$.

6. As an example, a brief quotation describing the streets of London in the late 18th century: 'At this time the streets of London were as filthy, muddy and polluted as a thousand dung heaps set side by side. Moreover, they were ten times as dangerous as a battle field and as rarely cleaned as the cell of a lunatic asylum...'.

7. In the early 1990 s the poor made up $60-70 \%$ of both the urban and the rural population in Bolivia (World Bank, 1990).

8. According to an analysis of statistical data operated by Tannuri-Pianto et al. (2004), this represented $68 \%$ of urban employment in 2002. 
9. This implied a deficit of 15\% of overall housing, a deficit which rose to 26\% in 1995 (Szalachman and Raquel, 1999).

10. It is also at this time, in 1992, that the NGO PRODEM, which since 1986 had specialised in microcredits for production purposes, became Banco SOL $<$ www.bancosol.com.bo/historia.html $>$.

11. A name adopted by the inhabitants in the early 1960s with reference to the synthetic fabric that was then making its appearance on African markets.

12. The issue of the link between preservation of the natural environment, economic cost and the allocation of this cost to the population has also been dealt with comparatively in three urban Latin American regions in Cuba, Argentina and Bolivia. See on the subject Bolay et al. (2005).

13. Internalising the costs means the inclusion of possible human health costs and the indirect investments (in public infrastructures, for instance) in the real value of a good's production.

14. One may mention the theories of the centres and peripheries which arose in the wake of studies conducted in the 1960s and 1970s by urban researchers including Prebisch (1963) and Furtado (1970).

15. According to the World Bank, quoted in Rakodi, 2002.

16. $82.6 \%$ in more developed countries and $56.4 \%$ in less developed regions.

17. The notion of urban governance (Le Galès, 1995), or of 'good governance' in the sense in which it is used by the World Bank (World Bank website on governance: < www.worldbank.org/wbi/governance/ > ) is relevant here (Santiso and Nitze, 2001).

18. One example, among many others, is what was done in Mauritania by the NGO GRET (Creusot, 2002).

\section{REFERENCES}

Ascher, François, 1995, Métapolis ou l'avenir des villes, Paris: Odile Jacob.

Ascher, François, 2000, Ces événements nous dépassent, feignons d'en être les organisateurs. Essai sur la société contemporaine, Paris: éd. l'Aube.

Bassand, Michel, 2004, La métropolisation de la Suisse, Lausanne: PPUR.

Bassand, Michel, Du, Thai Thi Nogc, Tarradellas, Joseph, Cunha, Antonio and Bolay, Jean-Claude (eds), 2000, Métropolisation, crise écologique et développement durable; l'eau et l'habitat précaire à Ho Chi Minh Ville, Vietnam, Lausanne: PPUR.

Bolay, Jean-Claude, 1988, 'Relato de una migración intranacional en México: el caso de Toluca y del Estado de México', in Actas Latinoamericanas de Varsovia, University of Warsaw.

Bolay, Jean-Claude, 1998, 'Habitat des pauvres en Amerique latine', in P. Rossel, M. Bassand and M.-A. Roy (eds), Au-delà du laboratoire, les nouvelles technologies à l'épreuve de l'usage, Lausanne: PPUR.

Bolay, Jean-Claude, 2002, 'Pratiques urbaines et planification en Amérique latine: Alternatives pour une gestion participative de l'habitat des pauvres en Bolivie', in Dansereau, Francine and NavezBouchanine, Françoise (eds), Gestion du développement urbain et stratégies résidentielles des habitants, Paris: L'Harmattan.

Bolay, Jean-Claude, 2004, 'World Globalisation, Sustainable Development and Scientific Cooperation', International Journal of Sustainable Development, Vol.7, pp.99-120.

Bolay, Jean-Claude and Du, Thai Thi Ngoc, 1999, 'Sustainable Development, Urbanization and Environmental Risks: The Priority of Local Actions in Ho Chi Minh City, Vietnam', Journal of Urban Technology, Vol.6, No.2, pp.65-85.

Bolay, Jean-Claude and Rabinovich, Adriana, 2004, 'Intermediate Cities in Latin America, Risks and Opportunities of Coherent Urban Development', Cities, The International Journal of Urban Policy and Planning, Vol.21, No.5, pp.407-421.

Bolay, Jean-Claude, Cartoux, Sophie, Cunha, Antonio, Du, Thai Thi Ngoc and Bassand, Michel, 1997, 'Sustainable Development and Urban Growth, Precarious Habitat and Water Management in Ho Chi Minh City, Vietnam, Habitat International, Vol. 21, No. 2.

Bolay, Jean-Claude, Pedrazzini, Yves, Rabinovich, Adriana, Catenazzi, Andrea and Garcia Pleyan, Carlos, 2005, 'Innovations in the Urban Environmental and Social Disparities in Latin America: The Shift from Technical to Social Issues as the True Challenge of Change', Habitat International, Vol.29, pp.627-645.

Boyle, T.C., 1982, Water Music, Boston, MA: Atlantic-Little, Brown.

Carley, Michael, 2001, 'Top-down and Bottom-up. The Challenge of Cities in the New Century', in M. Carley, P. Jenkins and H. Smith (eds), Urban Development \& Civil Society. The Role of Communities in Sustainable Cities, London: Earthscan. 
Creusot, Anne-Claude, 2002, Financement de l'habitat social en Mauritanie: l'expérience du programme Twize, Paris: GRET.

Durand-Lasserve, Alain and Poyston, Lauren (eds), 2002, 'Holding their Ground. Secure Land Tenure for the Urban Poor in Developing Countries', London: Earthscan.

Evans, Peter, 2002, 'Political Strategies for More Livable Cities. Lessons from Six Cases of Development and Political Transition', in P. Evans (ed.), Livable Cities. Urban Struggles for Livelihood and Sustainability, Berkeley and Los Angeles, CA: University of California Press.

Farvacque-Vitkovic, Catherine and McAuslan, Patrick, 1993, Politiques foncières des villes en développement, Paris: Adef.

Furtado, Celso, 1970, 'Théorie du développement économique', Paris: PUF.

Gulyani, Sumila and Debomy, Sylvie, 2002, Upgrading lo Low Income Settlements. Country Assessment Report. Cameroon, Washington, DC: AFTU $1 \&$ 2, World Bank document.

Hurni, Hans, Wiesmann, Urs and Schertenleib, Roland (eds), 2004, Research for Mitigating Syndromes of Global Change. A Transdisciplinary Appraisal of Selected Regions of the World to Prepare Development-Oriented Research Partnerships, Bern: National Centre of Competance in Research (NCCR) North-South, University of Berne.

INSEE: < www.insee.fr/fr/ffc/Ipweb/2003/ip926/definitions.htm > , Paris.

Kropp, J., Lüdeke, M.K.B. and Reusswig, F., 2001, 'Global Analysis and Distribution of Unbalanced Urbanization Processes: Favela Syndrome', Gaia, Vol.10, No.2, pp.109-121.

Lautier, Bruno, 1994, Economie informelle dans le tiers-monde, Paris: La Découverte.

Le Galès, Patrick, 1995, 'Du gouvernement des villes à la gouvernance urbaine', La revue française de science politique, No.45/1.

Lieberherr, Françoise, 1998, Waste, Waste Nothing but Waste. From 12th-19th Century Paris to 20th Century Developing Countries, Bern: SDC.

Percq, Pascal et le Groupe de Salvador, 1994, Les habitants aménageurs, Paris: édition de l'aube.

Pradhan, Menno and van Soest, Arthur, 1995, 'Formal and Informal Sector Employment in Urban Areas of Bolivia', Labour Economics, No.2, pp.275-297.

Prebisch, Raul, 1963, 'Transformación y desarrollo. la gran tarea de America Latina', Mexico City: Fondo de Cultura Economica.

Rakodi, Carole, 2002, 'A Livelihoods Approach - Conceptual Issues and Definitions', in C. Rakodi and S. Romaya (eds), 2002, Building Sustainable Urban Settlements. Approaches and Case Studies in the Developing World, Urban Management Series, London: ITDG Publishing.

Ruffin, François, 2003, 'Dans les ghettos de la pauvreté urbaine. Le logement social, entre pénurie et ségrégation', Le Monde, Diplomatique, November 2003, p. 4

Santiso, C. and Nitze, P.H., 2001, 'Good Governance and Aid Effectiveness: The World Bank and Conditionality', in School of Advanced International Studies, John Hopkins University, USA', The Georgetown Public Policy Review, Vol.7, No.1 (Fall 2001).

Sachs, Ignacy, 1997, L'écodéveloppement: Stratégie pour le XXIe siècle, Paris: Syros.

Sethuraman, S.V., 1997, Urban Poverty and the Informal Sector. A Critical Assessment of Current Strategies, New York: UNDP, < www.ilo.org/public/english/employment/recon/eiip/publ/1998/urbpover.htm > .

Szalachman, R. and Raquel, 1999, Un perfil del déficit de vivienda en Bolivia, 1992, Santiago de Chile: CEPAL

Tannuri-Pianto, Maria, Pianto, Donald,M. and Arias, Omar, 2004, 'Informal Employment in Bolivia: A Lost Proposition?', in Econometric Society, series Econometric Society, Latin American Meetings, No.149, < http://repec.org/esLATM04/up.29987.1081954718.pdf >

United Nations, 2005, The Millenium Development Goals Report 2005, New York: UNO < http://unstats. un.org/unsd/mi/pdf/MDG\%20Book.pdf >

United Nations, Department of Economic and Social Affairs, Population Division, 2002, World Urbanization Prospects. The 2001 Revision, New York: UNO, $<$ www.un.org/esa/population/publications/wup2001/WUP2001_CH1.pdf >

United Nations, Department of Economic and Social Affairs, Population Division 2003, World Urbanization Prospects. The 2003 Revision, New York: UNO.

United Nations General Assembly, 2000, Resolution adopted by the General Assembly 55/2: United Nations Millenium Declaration, New York: UNO, <www.un.org/ millennium/declaration/ares552e.htm $>$.

UN-HABITAT (United Nations Human Settlements Programme), 2003, The Challenge of Slums. Global Report on Human Settlements 2003, London: Earthscan.

UNCHS, 1999, Urban Poverty in Africa. Selected Countries' Experiences. Africa Forum on Urban Poverty, Nairobi: UNCHS 
UNCHS, 2003, The Challenge of Slums. Global Report on Human Settlements 2003, London: Earthscan. Vaillant, Emmanuel, 2000, 'Le Portugal éradique ses bidonvilles', Le Monde Diplomatique, Jan. 2000.

Wakely, Patrick and You, Nicholas (eds), 2002, Implementing the Habitat Agenda. In Search of Urban Sustainability, UN-HABITAT, London: DFID, DPU.

Weisbrot M., Baker, D., Kraev, E. and Chen, J., 2001, 'The Scorecard on Globalization, 1980-2000: Twenty Years of Diminished Progress', Center for Economic and Policy Research, Washington, DC. World Bank, 1990 Bolivia Poverty Report, Washington, DC, World Bank document.

World Bank, 2001, The Informal Economy and Local Economic Development, Program and Project Options, Washington, DC, World Bank, <www.worldbank.org/ urban/led/index_informaleconomy.html > . 